\title{
THE CLASSICAL ASSOCIATION OF SOUTH AFRICA: FURTHER DOCUMENTS 1955 - 1959
}

\author{
WJ Henderson (University of Johannesburg)
}

Since the publication of the article on the Classical Association of South Africa (CASA), covering the period from 1955 to $1961,{ }^{1}$ more documents, all from files of the CASA Executive, which were not available at the time of writing, have been added to the archive, which is kept in the School of Ancient Languages and Text Studies at North-West University. It is therefore necessary to place these documents on record in order to present a fuller account of the activities of the Association during the early years of its existence. The documents offer testimony of the dedication and enthusiasm of the early members, of how they surmounted problems of communication and travel, of the creation of international links, and of the struggle to preserve the Classical tradition. They also reveal much about the issues, attitudes and mind-set of the period.

\section{Administration 1955-1956}

General

A letter from Daphne Hereward (Royal Holloway College, 27 April 1955) to Mr A E Thorpe (University of the Witwatersrand) is worth quoting in full for what it reveals about the early relations, aspirations and attitudes between Classicists in South Africa and those in the UK.

Last January I wrote a letter to Mr [C P T] Naudé, whom I believed to be the Secretary of your Classical Association, advocating that an Association such as yours should initiate a scheme for making microfilms of manuscripts and out-of-print Classical books and periodicals and storing them somewhere safer than the libraries in the world's capital cities where most of them now are.

Since Mr Naudé was not in Johannesburg, the letter was, I am told, sent to him in Holland, and he then forwarded it to you. He also wrote to me saying that you were now the secretary of the Association.

That being so, I thought that I would write and reiterate the appeal for somebody to initiate such a scheme; although it would be

Henderson 2004. As in the previous articles, the following abbreviations are used to designate the members of the Executive Committee: $\mathrm{C}=$ Chairperson, $\mathrm{S}=$ Secretary, ST $=$ Secretary-Treasurer, $\mathrm{EC}=$ Executive Committee. 
a large undertaking when it was finished, it could be begun in a small way by selecting microfilms from those already made by the Jesuits, at St Louis, and finding somewhere - a school in a village, perhaps - to put them.

I wish that I could offer to help with a dramatic gesture like an enormous cheque, but I am afraid that all I can do is to make one or two suggestions for raising money by subscription.

One way would be to print postcards containing an appeal to support the scheme by buying a similar postcard (for, say 5/-) and sending it on to somebody civilized enough to respond to the appeal. Then the person who gets it, flattered at being called civilized, buys a similar one and sends it to one of their ( $\mathrm{sic}$ ) friends, and so it goes on and on.

Another would be to circularize the secretaries of other Classical Associations and ask them to give the scheme publicity, so that they could circularize school-teachers and lecturers and students. And, when you have got a little money, you could buy advertisementspace and television-time. ${ }^{2}$

I might be able to compose postcards and design advertisements, but I should imagine that you have somebody in South Africa who could do that better.

But I do hope that something will be done; every month or so we read about some new weapon of Destruction — we must do this, and soon.

Yours very truly: Daphne Hereward. ${ }^{3}$

The Association referred to here is the Johannesburg Classical Association, and there is no evidence that the suggestions were ever acted upon.

\section{First Conference, 4-7 April 1956, Pretoria}

The Classical Association of South Africa as it is constituted today was established in April 1956. Responding to the desire among South African Classical scholars for such an association, the convener of the interim committee, Dr W J G Lubbe, sent out a circular announcing the foundation conference to be held at Pretoria University on 4-7 April 1956 and inviting scholars to participate. Prof C A van Rooy proposed that there be discussion of the papers, that shorter contributions

2 At the time this would have been impossible: South Africa got television only 25 years later.

3 Daphne Hereward, a New Zealander by birth, subsequently became a noted epigraphist. 
would vary and lighten the programme, that a central theme should be chosen for future conferences, and that there should be an excursion. ${ }^{4}$ Those from further afield were encouraged to attend as it was hoped that travel and accommodation costs would be shared on a pro rata basis. A tentative programme was added for comment. $^{5}$

Another circular (in English and Afrikaans) followed in which the responses (24 replies out of the 36 sent) of colleagues concerning the arrangements were summarised as follows:

1. That the conference would be held on Wednesday 4 to Saturday 7 April at the University of Pretoria;

2. That at this foundation meeting decisions would have to be made as to whether the proposed association would be a country-wide organisation or one with regional branches; also concerning the date, place and frequency of meetings; concerning the defrayal of expenses of conferences; and any other matters that might arise;

3. That the expenses of this conference be shared pro rata among participants;

4. That the chairpersons of conference sessions should be rotated;

5. That the unavoidable absence of some scholars was regretted;

6. That an appeal be made to each university to send at least one representative to the conference;

7. That participants consider the possibility of a central theme for the next conference;

8. That the programme be arranged to make provision for as many speakers as possible;

9. That speakers be thanked in anticipation and politely requested kindly to adhere to their allotted time and to notify the secretary of any aids required for their presentations; that votes of thanks to speakers be limited to 10 minutes; that participants, especially those not offering papers, offer short communications on, for example, books, a particular topic or a problem relevant to Classical studies;

10. That delegates inform the secretary about the possibility of their being accommodated by family or friends, or, for other arrangements, to provide the time, manner of arrival and duration of stay;

Van Rooy to S, 5 January 1956.

Circular dated 20 January 1956. Dr Lubbe served the Classics in South Africa well, both as Latinist and administrator, into the 1980s, before turning his attention and talents to, inter alia, the Afrikaans Protestant Church of which he was a founder-member; he died on 2 January 2017, at the age of 94. 
11. To keep account of expenses incurred to facilitate financial matters at the end of the conference;

12. That delegates make suggestions for the organisation and success of the conference. ${ }^{6}$

A press release about the conference was sent to The Star, The Pretoria News, Die Transvaler, Die Vaderland and The Rand Daily Mail. In this, reference was made to the establishment of the association, the papers to be read, the fact that two-thirds of the country's Classicists were to attend, the intention to extend membership to school-teachers and students, the existence of the earlier Classical Association started in 1927, and that the Rector of the University of Pretoria, Prof C H Rautenbach, would host a luncheon for the delegates. ${ }^{?}$

\section{Administration 1956-1957}

\section{General}

For the first time all the documents had to be posted by registered mail to the new Secretary, Prof Smuts. These included the Minutes typed on wax sheets, copies of the circulars, correspondence, a list of the names of university teachers, a circular to those at the Universities of South Africa, Pretoria, Potchefstroom ${ }^{8}$ and Witwatersrand (as well as at Natal, Bloemfontein and Rhodes, who were free to choose to join either the southern or the northern branches) announcing a meeting on 20 October 1956 to establish the Northern Regional Branch, and a copy of the draft constitution. Matters such as circulating the minutes among school-teachers, the creation of letter-heads and the compilation of a guide for the spelling of Classical words in Afrikaans were mooted. ${ }^{9}$ The Minutes were circulated on 31 October 1956 and recipients were requested to study the constitution and propose additions, invited to join the Association and attend the forthcoming conference, and provide the names of persons who might be interested in the Association. ${ }^{10}$

Avignon conference

Soon after the conference the new Secretary, Prof F Smuts, wrote to the secretary of the organisers of the Congrès International pour le Latin Vivant in Paris, 2-6

\section{Circular dated 6 March 1956.}

7 Dated 30 March 1956. Luncheon: Rautenbach to Lubbe 14 March 1956; Lubbe to Rautenbach 21 March and 16 April 1956 (motion of thanks).

8 Now North West University.

$9 \quad$ Lubbe to S, 1 October 1956; reply S to Lubbe, 14 November 1956.

10 Dr Lubbe wrote a letter to the Department of Education requesting a list of Latin teachers in the Transvaal (now Gauteng), dated 29 November 1956. The list was sent to the Secretary on 15 January 1957. 
September 1956, regarding the proposed attendance of Prof H L Gonin — the first steps in joining the international body of Classical scholars. The historical letter read as follows:

Francois Smuts Scribae Conventus Sermonis Latini Studiosorum S(alutem) P(lurimam) D(icit)

Ex Africa non semper aliquid novi: vobis nuntiare volo in ultima parte Africae Meridianae studia antiquiora et amari et vigere. In urbe apte nominata Praetoria mense Aprili huius anni professorum linguarum Graecae Latinaeque conventu habito Societas Studiosorum Litterarum Graecarum Latinarumque Africae Meridianae (Classical Association of South Africa), complures iam annos intermissa, ab integro fundata est.

Hoc eodem conventu Prof Henri Gonin a societate nova delegatus est ut eius nomine illi conventui omnium sermonis Latini studiosorum interesset Avenione habendo.

Prof Gonin est professor sermonis Latini in Universitate Praetoriana idemque praeses vicarius Societatis Gallicae (Alliance Française) urbis Praetoriae.

Gratissimum mihi erit si me certiorem de omnibus rebus huius conventus feceris et praeterea de rebus his: primum num nomen Professoris Gonin accipere possis inter eos qui ad hunc conventum deligati sint; deinde num ei qui summam rerum Reipublicae Gallicae administrant quid auxilii praestent legatis ad conventum missis.

De hac re iam ad legatum Gallicum scripsi, sed nondum responsum accepi. Novissime tamen mihi nuntiatum est ubi scriba esset conventus: te igitur ipsum per hanc epistulam adii ut de omnibus rebus certior fierem.

Cum Prof Gonin paucis diebus profecturus sit hinc, gratissimum mihi facies si quam celerrime mihi scripseris de his rebus per epistulam aëriam, si potest. Alioquin poteris epistolam mittere ad Prof Gonin ipsum, qui praetorium Societatis Gallicae (All. Franc.) Lutetiae visitabit medio mense Iulio.

Maximam habebo gratiam si de te certior factus ero. Vale.

Prof Francois Smuts, professor serm. Lat. in Universitate Stellenbossiensi et scriba Sociatatis. ${ }^{11}$

11 Letter dated 17 June 1956. Translation: 'François Smuts expresses his best wishes to the Secretary of the Conference of Latin Scholars. Something new does not always come 
A letter from the congress secretariat (in French) confirmed Prof Gonin's participation ${ }^{12}$ and he reported on the proceedings at the next CASA conference in 1957. ${ }^{13}$ Earlier, on 10 October 1956, he sent a letter to Prof Smuts from the South African Embassy in Rome with an Afrikaans translation of the report issued by the organisers on the day the congress ended (6 September 1956). The report was to be submitted to South African newspapers. ${ }^{14}$ The full text (in Prof Smuts's translation) is as follows:

\section{INTERNATIONAL CONGRESS AT AVIGNON TO MAKE LATIN A LIVING LANGUAGE}

Today (Sept. 6) the International Congress to make Latin a living language, held in Avignon at the Publisher Edouard ThéodoreAubanel, whose zeal for humanistic studies is well known, terminates its activities. The leader of the Congress was Monsieur Jean Capelle, Director General of Education in French West Africa. The Congress reached complete unanimity on the pronunciation of Latin, the method to be followed to enrich its vocabulary with all

out of Africa: I wish to announce to you that in the furthest part of South Africa the study of antiquity is loved and flourishes. In the city aptly called Pretoria, in April of this year, a conference of professors of Greek and Latin was held and the Classical Association of South Africa, which had been interrupted for several years, was established anew. At this same conference Prof Henri Gonin was delegated by the new Association to attend in its name that conference of all scholars of Latin to be held at Avignon. Prof Gonin is Professor of Latin at the University of Pretoria and also ViceChairman of the Alliance Française of the city of Pretoria. I shall be most grateful if you would inform me about everything regarding this conference and especially the following: firstly, whether you could accept the name of Professor Gonin among those who have been delegated to this conference; secondly, whether the government of the Republic of France offers any assistance to the delegates sent to the conference. I have already written to the French Consul about this matter, but have not yet received a reply. However, I recently learned where the secretary of the conference is: I have therefore approached you yourself with this letter in order to be fully informed about everything. Since Prof Gonin is leaving from here in a few days, you will make me very happy if you write to me as quickly as possible on these matters by aerogram - if possible. Otherwise you will be able to send the letter to Prof Gonin himself; he will be visiting the headquarters of the Alliance Française in Paris in the middle of July. I shall be most grateful if you keep me informed. Farewell. Prof François Smuts, Professor of Latin, University of Stellenbosch and Secretary of the Association.'

Cf. Henderson 2004:92.

Letter (signature illegible) to S, 22 June 1956. Cf. Henderson 2004:90.

14 Gonin to S, 10 October 1956. Three other communications (by Mr Guercio and Professors Marache and Peeters) were sent: secretariat to S, 19 September 1956. 
necessary terms to express modern life, on the simplification of its grammar, and on the problem of educational method.

Two hundred and fifty scholars from 21 countries — the élite of Latinists of the whole world - attended the Congress. Its purpose was the resurrection of a language reputed to be dead, but one for which the need is felt to ensure a better understanding between nations.

The sessions were led by Monsieur Blache, Rector of the Academy of Aix-Marseille, by Senator Quinto Tosatti, President of the Institute for Latin Studies at Rome, by Monsieur Jean Bayet, Director of the French School in Rome, by Monsignor J J Delgado, Dean of the University of Salamanca, by Prof Erich Burck, President of the Association of German Philologists.

On September 4 the Roman ruins of Orange and Vaison were visited under the direction of Monsieur S. Gagnière, Director of the 12th Division of Antiquities. On September 5 the delegates attended a supper by candle-light held in the Grand Audience Chamber of the Palace of the Popes. The supper was enlivened by a display of Mediaeval dances organised by Mme Véra Centkowska. In the course of this function Monsieur Boissier, Prefect of Vaucluse, stressed the usefulness of Latin at large international conferences.

Anyone interested in this Congress, who would like to be kept informed of future developments, may obtain information from Monsieur Edouard Théodore Aubanel, Editeur en Avignon.

NB We shall be pleased to receive two copies of the edition of your paper in which this notice appears, with a view to the archives of the Congress.

Prof Smuts subsequently sent a press release, with translations of Prof Gonin's report attached, to Afrikaans and English newspapers. ${ }^{15}$

\section{The next conference}

It was decided to have four key speakers at the conference. Prof G P Goold was approached to deliver a paper on the decipherment of Linear B and the progress since the Ventris-Chadwick article in JHS 1953; he gladly accepted - in Afrikaans, and also offered to present it in Afrikaans. ${ }^{16}$ Prof T J Haarhoff was invited to offer a paper on a topic of his own choice and he too accepted, as did

S to Editors, 5 November 1956.

16 Van Rooy to S, 18 August 1956; S to Goold, 7 September 1956. 
Prof K D White and Dr O A Weber. ${ }^{17}$ Compiling and finalising the programme (including an excursion to the KWV and a wine-farm), dates and duration of the conference, circulating minutes and programme, and arranging accommodation with private individuals were dealt with in frequent to-and-fro correspondence. ${ }^{18}$ The final dates did not suit all the universities and it was suggested that in future the conference should be held in alternate years, with the regional branches meeting in between. ${ }^{19}$ Another issue that was sporadically raised was the compilation of a list of periodicals available in South Africa. ${ }^{20}$

The notion of having a session where delegates could present short reports on their current research could not be included in the programme. ${ }^{21}$ The idea of a symposium elicited several offers. Prof White offered to bring along plans and drawings of Classical sites submitted by the students of Classical Culture at Rhodes University (e.g. of the sanctuary of Asclepius at Epidaurus, the Acropolis at Athens, and Hellenistic town planning). He also suggested that an exhibition of recent books on the Classics be arranged, particularly for the benefit of teachers. If there was going to be a session on the teaching of Latin, he proposed a discussion of Latin quantity and scansion which he would be willing to lead. Others who offered to take part in a symposium were Dr Lubbe on the future task of teachers of the Classics, Mr Thorpe on the history of Lugdunum and Dr Naudé on the influence of Ammianus Marcellinus on Gibbon's causes for the Decline and Fall. Prof Van Rooy offered to present a slide-show on the palace at Knossos, or the excavations at Pompeii, Herculaneum and Ostia. ${ }^{22} \mathrm{He}$ had also attended a lecture in Bloemfontein given by a visiting Dutch theologian and archaeologist, Dr A G

17 S to Haarhoff, 26 August 1956; Haarhoff to S, 2 September 1956; White to S, 10 October 1956; S to Haarhoff 14 November 1956; S to White, 14 November 1956; Lubbe to S, 28 December 1956; Viljoen to S, 8 January 1957; Weber to S, 14 January 1957; Lubbe to S, 15 January 1957.

18 Viljoen to S, 16 and 24 October 1956; S to Paap, 14 November 1956; answered (in Afrikaans again) by Goold, 30 November 1956; Lubbe to S, 28 December 1956; Haarhoff to S, 20 December 1956; S to Lubbe, 1 January 1957; S to Lubbe, 4 January 1957; Naudé to S, 7 January 1957; Viljoen to S, 8 January 1957; Gonin to S, 19 January 1957; S to Lubbe, 5 February 1957; Goold to S, 5 February 1957 (in Afrikaans). Dr Lubbe kept a meticulous record of his correspondence in his neat handwriting.

19 Postma to Smuts, 14 January 1957 (postcard); J H Grobler to S, 4 February 1957; Coetzee to S, 7 February 1957.

20 Lubbe to S, 1 October 1956; Goold to S, 30 November 1956; Lubbe to S, 15 January 1957.

${ }^{21}$ Van Rooy to S, 5 January 1956; Lubbe to S, 20 January 1956; 6 March 1956 (circular with provisional programme); Dr A Lagouros to S, 20 January 1957 (on Plotinus); C to Lagouros, 10 May 1957.

22 White to S, 3 December 1956 (received only on 23 January 1957); Van Rooy to S, 26 December 1956; Naudé to S, 7 January 1957; S to Lubbe 23 January 1957. 
Luiks, on excavations at the Roman cities of North Africa, and recommended inviting him to repeat the talk at the conference. ${ }^{23}$ In the final programme Dr Luiks was fitted in and a symposium held on the teaching of Latin at schools. ${ }^{24}$

For most delegates attendance entailed long distances by train, an aspect that was presented as justification for appeals for financial support from the universities. ${ }^{25}$ The Secretary wrote to the South African Railways about the possibility of concessions on return rail tickets for delegates to the Stellenbosch conference. In reply the SAR stated that concessions were granted to delegates to the most important meetings of recognised religious denominations and of agricultural unions only. ${ }^{26}$

The rectors and principals of the universities were informed of the Association and the forthcoming conference and requested to consider (1) the possibility of annually meeting the travelling expenses of at least one delegate from the relevant university to the annual conference of the Association and (2) the possibility of financial aid to enable the Association to publish a journal of Classical studies. The letter to the Rector of Stellenbosch University also asked for permission to use the university's lecture rooms and for the Rector to welcome the delegates. ${ }^{27}$ In reply the University of Pretoria stated its policy of covering the expenses of a Head of Department only, in this case Prof P V Pretorius, to whom the grant had already been made on 7 December $1956 .{ }^{28}$ Rhodes University would pay $50 \%$ of the expenses of staff members attending conferences, but from an annual allocation to the Principal, and nothing for the proposed journal. The University of the Witwatersrand agreed to pay the expenses of only one delegate, and required more details concerning the journal. The University of South Africa decided to carry the expenses of one delegate, provided the delegate presented a paper, and to refer the matter of a contribution to the journal to the Publications Committee. The policy of the University of Cape Town was to pay the travelling expenses of a delegate appointed by the University, to wit, Prof Goold. The University of Stellenbosch agreed to finance a delegate to future conferences and requested further details about the journal. The University of the Orange Free

23 Van Rooy to S, 5 February 1957.

24 Programme; $c f$. also Editors 1958:166; Henderson 2004:92. Dr Luik's initial there was incorrectly given as $\mathrm{W}$.

25 Lubbe to Registrar (Pretoria), 10 January 1957; Rector (Stellenbosch) to S, 11 January 1957; Lubbe to S, 15 January 1957.

26 S to Divisional Manager SAR, 3 January 1957; General Manager SAR, 14 January 1957; S to Lubbe 23 January 1957.

$27 \quad$ S to principals, 7 January 1957.

28 Shortly before the conference, a telegram arrived with the information that Prof Pistorius would not be attending the conference; Lubbe to S, 8 February 1957. 
State could not fund attendance at conferences or a journal. ${ }^{29}$ Dr Lubbe informed the Secretary that application for financial support for the journal could be made to the Publication Committee of Pretoria University, the National Council for Social Research and/or the Council for Adult Education. ${ }^{30}$

Letters arrived from persons who wished to attend the conference. The most remarkable and interesting came from Rev P J Loseby, who had been present at the inaugural meeting of the Stellenbosch Branch of the Classical Association [on 9 August 1927] and had also given a talk at the Stellenbosch branch [on 5 July 1928]. He recalled a lecture on the Minoan excavations [by Prof Theo le Roux of UCT, on 25 March 1929], which he had found particularly interesting as he had been born in the old home of the Evans family. He was hoping his hearing would be good enough. ${ }^{31}$ Among students and teachers mentioned as likely to be interested in attending the conference, a few later went on to play significant roles in the activities of CASA. ${ }^{32}$

\section{CASA on radio}

In correspondence with the Talks Supervisor of the SABC Johannesburg, Prof White mentioned the idea of having the conference publicised; the former passed on the matter to Mr Dewar McCormack, the English Programme Organiser, who would wait to be contacted by the Secretary, with a view to arranging an interview with a Classicist from Cape Town University. ${ }^{33}$ In the meantime Prof White contacted Mr McCormack and gave him information about the Association. ${ }^{34}$

29 Registrar (Pretoria) to S, 17 January 1957 (nothing about support for the journal); Registrar (Rhodes) to S, 22 January 1957; Registrar (Witwatersrand) to S, 22 January 1957; Registrar (Cape Town) to S, 7 February 1957; Registrar (Stellenbosch) to S, 15 February 1957; S to Rector, 10 May 1957; Rector (Free State) to S, 26 February 1957. Unisa later declined to support the journal: Registrar to C, 4 April 1957. Summary on file.

$30 \quad$ Lubbe to S, 23 January 1957.

31 Loseby to S, 7 February 1957. Cf. Henderson 2013:131, 136.

32 K Matier and M de Lisle (Rhodes; White to S, 3 December 1956), and D M Kriel (Pretoria, Lubbe to S, 28 December 1956). Dr Ken Matier, formerly Professor of Classics at the University of Natal [now Kwazulu Natal] (Durban), passed away on 26 December 2017.

$33 \quad$ White to S, 12 January 1957.

34 White to S, 24 January 1957. Prof White was preparing a series of five talks on 'Our debt to Greece and Rome' for the SABC, to be broadcast weekly on the English transmission from 29 March to 26 April 1957. 


\section{Visit of Prof Wagenvoort}

The Secretary wrote to the Department of Education, Arts and Science about the possibility of inviting Prof $\mathrm{H}$ Wagenvoort to visit South Africa under the South African-Netherlands Exchange of Scholars scheme. In his letter Prof Smuts mentioned the decision of CASA to invite Prof Wagenvoort and proceeded to justify the decision. Scholars in various other disciplines had already been invited to South Africa, but as yet no Classicist. Classical Studies in South Africa were going through a difficult time, associated with the enormous technical and material development of the country, and for that reason it was all the more essential to maintain a balance, where Classical Studies provided the necessary cultural background to Western civilisation. In addition, South Africa was far removed from the cultural centres of Europe and contact with Holland would be fruitful. Finally, the Suid-Afrikaanse Akademie was also concerned about the decline of Classics in South Africa. In 1954 and 1955 the matter had been on the agenda of the AGM and a sub-committee had been appointed. The letter ended with a short CV of Prof Wagenvoort: his career first as Professor of Latin at the University of Groningen and then emeritus after 25 years at the University of Utrecht, his preeminence among Dutch Classical scholars, his influence through his publications (a short list attached) and students (56 doctorates), and his excellence as a speaker. The Department of Education, Arts and Science replied that the matter would be discussed at the next meeting to be held in Pretoria on 3 December 1956. ${ }^{35}$

\section{Second Conference, 12-15 February 1957, Stellenbosch}

\section{Proceedings}

Telegrams of good wishes for the conference arrived on the first day of the conference: from Proff A Petrie, W Postma and Erika Theron (Mayor of Stellenbosch). As the Chairperson, Prof A H R E Paap, was abroad, the annual report was tabled by the Acting Chairperson, Prof Smuts. Details have been reported elsewhere ${ }^{36}$ and only two further items need be added here: the choice of the Rhodes University Classicists to be included in the southern regional branch; and a vote of thanks to the publishers who displayed books during the conference: Oxford University Press, Longmans Green \& Co., Juta's, Maskew Miller and Universiteitsuitgewers, Stellenbosch.

$35 \mathrm{~S}$ to Mr Van der Walt, Secretary of Education, Arts and Science, 13 September 1956; reply to S, 5 November 1956 .

36 Editors 1958:166; Henderson 2004:92. 
Prof White proposed a museum exchange scheme with Italy:

Whilst in Italy in 1953/4 I discussed with Italian authorities the possibility of an exchange of material between them and the Union [of South Africa] — viz. Italian museums to send us surplus Classical material, and the Union museums to send them surplus geological, paleontological, ethnographic material, etc.

A resolution on these lines was passed unanimously at the 1954 Conference of the SA Museums Association at Salisbury. The resolution, with a covering letter, went to Minister [ $\mathrm{J} \mathrm{H}]$ Viljoen, asking for his support (not financial, but in order to obviate customs and other difficulties). The response was completely negative.

I've now suggested that the matter be reopened and that Conference adopt the following resolution:

1. The Classical Association supports the idea of a Museum Exchange Scheme between South Africa and Italy on the lines laid down in the memorandum submitted by Professor White to the Museums Association, and recommends that steps be taken to implement the scheme.

2. That the Museums Association be invited to submit in general terms information about the kind of material which they would be prepared to exchange.

3. That the Minister for Education, Arts and Science be asked to take the initiative (a) by setting up a Joint Committee of this Association and the Museums Association to determine the allocation of material, etc.; (b) by negotiating at ministerial level with the Italian authorities in order to waive custom duties, etc. and in other ways to further the scheme.

Note: It seems to me essential for someone to interview the minister and personally to enlist his interest. Correspondence is useless.

The proposal was accepted (but without the 'etc.'s and 'Note'). ${ }^{37}$

37 White to S, undated (12 February 1957?); Goold to S, undated (12 February 1957?);

Editors 1959:128, 129; Henderson 2004:92-93. 
Another proposal gave rise to an intriguing exchange of correspondence. Dr W J Nijgh wrote as follows (translated from the Dutch):

To the Management, Royal Company of Exploitation of Oil-wells. Dear Sirs, I am a member of the Classical Association of South Africa, whose Honorary President is Prof Dr T J Haarhoff of Johannesburg. The Association has decided that annually a conference paper should be presented in Latin. In Amsterdam there has existed for many years the Hoeuft prize for the best annual Latin poem. I would be delighted to see that Royal would act as a Maecenas in the form of a 'Henry Deterding' prize of, for example, $£ 50$, for the best Latin poem to promote the idea of the Greater Netherlands. I beseech you to be so kind as to inform me that a request by the Classical Association as mentioned above will be considered benevolently by you. With the highest regard, Yours sincerely...$^{38}$

The following reply arrived:

Dear Sir, with regard to your letter of 26 February last addressed to the Royal Company of Exploitation of Oil-wells we regret to inform you that we cannot consider the provision of a prize for the Classical Association of South Africa. With regards, Batavian Petroleum Company. ${ }^{39}$

At the closing meeting, the new Secretary-Treasurer, Dr Lubbe, tabled a declaration in which he stated the following:

- That the two conferences proved that there was a need among Classicists to join in the promotion of Classical studies in South Africa;

- That the scientific study of the Classics and its wider impact on the world were of the utmost importance for South Africa and would be advanced by the Association;

38 Nijgh to Batavian Petroleum Company, 26 February 1957. I wish to thank Prof Manfred Horstmanshoff, Emeritus Professor, Leiden University, for his kind assistance with the translation and additional information at:

https://la.wikipedia.org/wiki/Certamen poëticum Hoeufftianum,

https://nl.wikipedia.org/wiki/Royal_Dutch_Shell and

https://nl.wikipedia.org/ wiki/Grootneerlandisme.

39 Batavian Petroleum Company to Nijgh, 28 March 1957. Dr Nijgh was thanked for his efforts by the Chairperson, 11 May 1957. 
- That teachers at university and school should encourage interested persons to join the Association and work towards the development of Classics in South Africa;

- That Classics need not defend itself, since the centuries had already done that;

- That the education authorities be asked to promote the knowledge of Greek and Latin at school, for which later generations would thank them;

- That the Association expressed its gratitude to the teachers of Latin who are often unappreciated;

- That the following also be thanked: interested persons and nonClassicists who attended the conferences, the universities that supported delegates, and the press for publicity.

\section{Administration 1957-1959}

\section{General}

Letters of thanks and appreciation were sent to the Rector and the Registrar of the University of Stellenbosch for the reception and facilities, ${ }^{40}$ to the publishers for exhibiting books, ${ }^{41}$ to the mayor for her interest in the Association's activities. ${ }^{42}$

Some practicalities of the recent conference at Stellenbosch emerge from a letter by the Treasurer for the conference, Prof Goold, to Prof Smuts, Secretary for the conference. The cost of the entire conference (excluding travel) was $£ 150$, of which the universities contributed $£ 100$, leaving a shortfall of $£ 50$. Divided among the 30 delegates, this amounted to $£ 1.15 .0$ owed by each (including postage and small change). Prof Smuts had paid £1.1.6 into the kitty and therefore still owed $£ 0.13$.6. However, he was owed $£ 6.15$.0 for secretarial expenses, so a cheque for $£ 6.1 .6$ was sent to him. ${ }^{43}$

The Executive had to make decisions and recommendations on some matters arising from the minutes of the previous conference. ${ }^{44}$ The publication of the Acta, combined with the volume in honour of Prof Haarhoff, was being expedited by the Editorial Committee: funds were being collected from donors and a possible publisher (Blackwell or Balkema) approached. The papers of the

$40 \quad$ C to Rector and Registrar, 6 May 1957.

$41 \mathrm{C}$ to Oxford University Press, Longmans Green \& Co., Universiteitsuitgewers, 6 May 1957.

42 C to E Theron, 6 May 1957.

43 Goold to C, 24 April 1957.

44 ST to EC, 5 November 1957; Viljoen to C, 12 November 1957; Naudé to C, 13 December 1957; C to ST, 14 December 1957; ST to C, 26 December 1957; $c f$. Henderson 2004:92-3. 
conference were to be included. It had been pointed out that for a journal of more than just the Acta of the Association there would have to be a sufficient and steady supply of articles. ${ }^{45}$ Regarding the appointment of Honorary Members, it was suggested that any suitable persons interested in the Classics or general culture could be considered, but the final choice had to be made by the Executive and a clause to this effect added to the constitution. Prof Smuts had discussed the Museum Exchange Scheme with Prof Wagenvoort, who had encouraged the initiative and suggested including outsiders such as the Italian ambassador on the committee. ${ }^{46}$ Based on the general enthusiasm evinced during the conference and the sympathetic attitude of the press and in order to maintain momentum, there was some support for the next conference to be held in 1958 and not in two years' time. However, the newly-accepted constitution stipulated biennial conferences. ${ }^{47}$ A list of periodicals was being finalised; the next phase would be a catalogue of corpora and collections. ${ }^{48}$

Dr Lubbe compiled a list of members from the universities: Proff Goold and Paap, Messrs B L Hijmans and H W M Pope and Miss Faure (temporary) (Cape Town); Proff A Petrie and S Davis, and Mr B H P Farrer (Natal); Proff S J H Steven and Van Rooy and Messrs J P Louw and W J Richards (Orange Free State); Proff Coetzee and Postma, and Messrs $J$ J Coetzee and $J$ H Grobler (Potchefstroom); Proff Gonin and Pistorius, Drr Lubbe and De Kock and Mr L J D la Grange (Pretoria); Prof White, Mr H Hewitt and Miss L Baumbach (Rhodes); Proff Van Rensburg and Smuts, Drs A M Hugo and C Fensham, Mrs S de Vries and Mr P J Conradie (Stellenbosch); Prof Viljoen, Dr Weber and Mr Kriel (UNISA); Prof Haarhoff, Dr Naudé, Messrs Thorpe, Lagouros and G J Acheson (Witwatersrand); and Dr R Jacobs (Fort Hare). Others wishing to join were Judge C P Brebner, Mrs M Findley, Dr J M Fourie, Mrs M J Grootes, Dr Nijgh, Mr S Whiteley, Rev Loseby, Mr D Mikker, Mr P N J Snyman, Mr H L F Drijepondt and Dr J J Strasheim. ${ }^{49}$

The Genootskap Nederland-Suid-Afrika sent a letter to the regional branch secretaries in which a gift of Nijhoff's new publications for 1957 were offered to the university libraries which could choose works from a list up to the value of 300 florins..$^{50}$

45 Viljoen to C, 9 April 1957.

46 C to ST, 8 November 1957; 14 December 1957.

47 Naudé to C, 8 March 1957 (on behalf of Proff Van Rensburg and Viljoen and himself, in support of Prof Gonin's proposal at the conference); ST to EC, 5 November 1957; Editors 1959:132, 133, Clause 10; Henderson 2004:93.

48 Viljoen to C, 9 April 1957; 26 December 1958.

49 ST to C, 26 December 1957.

50 D. Pont to C, 7 August 1958, 13 September 1958. 
The Consul-General of the Netherlands, Dr N A C Slotemaker de Bruïne, drew Prof Smuts's attention to the calendar Imago for 1959 which had been compiled by the Nederlandse Klassiek Verbond and published by the Drukkery Ter Burg in Alkmaar. He had learnt from Prof Rollo of the forthcoming conference of CASA and wondered whether the calendar could be displayed during the conference. Prof Smuts gladly agreed to this and requested copies to take to the conference. $^{51}$ The 1959 calendar was, however, sold out and some publicity pamphlets for the 1960 edition (at 5 florins each) would be provided. ${ }^{52}$

Latin and Law

Concern was expressed at the news that the government of the time intended to abolish Latin as a requirement for the attorneys' admission examination (B.Proc.). Mrs Findley expressed a view shared by many: 'To let Latin fall away as a law subject seems to me to be bowing a little more to the idea which is already gaining ground, that only modern and practical subjects matter and the use of one's brain on purely cultural subjects is a waste of time. ${ }^{53}$ The Chairperson, Prof Smuts, sent a memorandum to the Ministers of Justice and of Education, Arts and Science for their sympathetic consideration. ${ }^{54}$ The main points of the memorandum (in Afrikaans) were: $:^{55}$

- The Association expressed its dismay at and strong protest against the proposed legislation.

- The retention of Latin was in the interests of general educational and cultural consciousness in South Africa.

- Latin and the studies associated with it had shaped one of the pillars of Western civilisation for more than a thousand years: the sources of our legal system are in Latin; many of our ideas of art and literature were transmitted to us in Latin; and a large proportion of Christian doctrine was originally written in Latin.

- It was the language medium of the Renaissance, the Reformation and science until nearly the close of the 17th century.

- Latin has contributed an enormous amount to the vocabulary and thought of the Western European languages (including Afrikaans).

51 C-G to C, 7 January 1959; C to S-G, 12 January 1959.

52 C-G to C, 24 January 1959.

53 Findley to C, 28 March 1957. Mrs Findley became an active member of CASA and served on the committee of the Western Cape Regional Branch (1962-3). Cf. Henderson 2005:115.

54 C to C R Swart and J H Viljoen, 20 April 1957 cf. Henderson 2004:93-94.

55 Afrikaans copy on file. 
- Students in literature and theology were therefore encouraged to take Latin as a subject and this would be a retrogressive step for students wishing to become attorneys.

- The Classical Association was aware of the fact that many schools no longer offered Latin, but was of the opinion that attempts should be made to remedy this situation rather than to abolish Latin for law studies. Similarly, although Greek and Hebrew were no longer or very rarely taught at school, they were still basic subjects for theological studies.

- The Suid-Afrikaanse Akademie vir Wetenskap en Kuns was also concerned about the decline of Latin at school and a committee was studying the matter and would probably soon submit requests to the various Departments of Education. The Chairperson of the Akademie, Prof F E J Malherbe, had recently stated: 'For many years the Akademie has concerned itself with the preservation of Latin at school, and although we do not want to make Latin compulsory for every pupil, we desire that an opportunity for the pupil to study Latin should be available at every school. It is therefore disturbing that Latin is no longer offered at rural schools, even for those who specifically ask for it, and the Afrikaner suffers a loss through official negligence of a primary cultural duty. We recently heard the result of this in Parliament when in all seriousness there was a plea for the abolition of Latin for jurists, as a means of meeting the shortfall / scarcity of Afrikaans-speaking attorneys and the fact that Afrikaners no longer learnt Latin at school'.

A letter from the Ministry of Justice pointed out that the matter fell under the Ministry of Education, Arts and Science. ${ }^{56}$ The Minister of Education, Arts and Science replied that the submission would receive consideration together with recommendations from a consultation between South African universities, but that the Cabinet would consider the matter; that no indication of the possible outcome could yet be provided as there were various points of view (including that of the national interest). ${ }^{57}$

Prof Smuts sent a letter to the Editor of Die Burger expressing gratitude for the article 'Prokureurs sonder Latyn?' ('Attorneys without Latin?') in Die Burger which argued that such legislation would be a retrogressive step that would not deliver more able attorneys. ${ }^{58}$ On the same day he also addressed a telegram and letter to Dr J H O du Plessis (House of Assembly) in time for the vote on the issue of Latin for attorneys, in which he drew attention to the article (copy included in the letter) and the information it contained, and made an urgent plea against the

\footnotetext{
56 Ministry of Justice to C, 4 May 1957.

$57 \mathrm{~J}$ H Viljoen to C, 6 May 1957.

$58 \mathrm{C}$ to Editor, 12 June 1957.
} 
proposed legislation. He referred to the representations made to the Minister by the teachers of law at the universities and the Law Society; he was therefore more concerned here with the justification for the legislation given by Minister Swart and others in Parliament: the diminishing number of schools offering Latin, which resulted in boys in rural areas being at a disadvantage if they wanted to become attorneys.

He pointed out that Latin was vanishing from schools where Latin had previously been taught, but that this obstacle could be overcome by determination and by private study, that such boys were more likely to study BA Law first, and that there were introductory courses available at university. He further pointed out that the situation of Latin at school was, in fact, not so dire. In the Transvaal Education Examinations the numbers of pupils taking Latin had grown from 548 in 1948 to 1053 in 1956 and constituted $20 \%$ of candidates. The numbers of schools in the Transvaal offering Latin had increased from 45 out of a total of $95(47,4 \%)$ in 1952 to 70 out of $119(58,8 \%)$ in 1956. In the Orange Free State there were 21 schools offering Latin in 1956, of which 12 were in rural areas, and in the Cape Province enrolments had increased by $15 \% .{ }^{59}$

In a telegram Dr Lubbe conveyed the news that the Law Faculties had protested against the draft legislation in a statement to the South African Press Association and had requested the Classical Association to support the protest; he advised independent action supported by Prof Smuts's memorandum. ${ }^{60}$ Two days later Dr Du Plessis wrote a personal reply to Prof Smuts with the information that the Cabinet, after consultation with Minister Swart, had decided to shelve the proposed legislation until the following year to allow more time for further deliberation; he also expressed the wish to consult with Professors Smuts and J P J van Rensburg on the issue. ${ }^{61}$

Just over a year later, Mr Pont of the Genootskap Nederland-Suid-Afrika informed Prof Smuts of a memorandum sent by the Society of University Lecturers in Law to the Minister of Education, Arts and Science regarding the proposed legislation abolishing Latin for the attorney examinations. The memorandum, reflecting the racist and sexist mentality and attitudes of the members of the Society of Lecturers in Law of that time, stated (translated from the Afrikaans):

1. The Society has taken notice of the draft bill to change the Law on Universities, 1955 (Law no. 61 of 1955) and in particular article 16 duodec (6).

\footnotetext{
59 C to Du Plessis, 12 June 1957.

$60 \quad$ ST to C, 17 June 1957.

${ }^{61}$ Du Plessis to C, 19 June 1957.
} 
2. If clause (6) of article 16 duodec became law, the legislator would abolish Latin as a requirement for the training of an attorney.

3. The Society, which represents lecturers in Law from all nine universities, hereby registers its serious objection to the abolition of Latin and strongly demands from the Honourable Minister of Education, Arts and Science that Latin should not be abolished and that the said clause be deleted from the draft bill before it is submitted to Parliament.

The reasons were given as follows:

i. The abolition of Latin is not in the interests of the legal profession in our country; it is a dangerous undermining thereof. Latin is one of the languages employed by both the legislator and the judge. Latin is the language in which a large portion of our inherited common law has been recorded. The abolition of Latin means that South African attorneys would in future no longer have the expertise (better perhaps 'ability') to have a command of our prevailing law and to serve the public properly. The quality of legal assistance to the public will suffer a serious deterioration.

ii. Knowledge of Latin brings with it command over an indispensable key to access to understanding of our law. It also implies a particular standard of education and mental discipline. The study of Latin exercises the intellect and that sense of logic that is indispensable for the jurist. Knowledge of Latin forms those character traits of precision and responsibility without which the attorney as practitioner and person is insufficiently equipped.

iii. The abolition of Latin means a lowering of educational standards. Western civilisation in South Africa cannot afford to diminish the level of education and development of the bearers of civilisation. We cannot afford to deprive ourselves of the competence and capability to act as educators and teachers of the undeveloped nations around us. If we wish to remain standing next to and in opposition to them, we must always set higher standards for ourselves and not lower existing standards. Nowadays already more pupils from Coloured schools in the Cape annually pass matriculation Latin than pupils from Afrikaans schools. If we ourselves become alienated from the foundations of our culture, how can we remain superior to or even the equals of others who are ever more eagerly absorbing culture?

iv. The modern state that aims to serve the common good, adapts to the demands of modern times and this is undoubtedly a time of unprecedented intellectual competition and a challenge to exert all our intellectual powers to achieve the best in every field. Our young men, who are alert, fully realise this and desire that our state and government should take measures with an eye on the future in such a way that we can compete in the world and resist all slackness and 
decline. The draft bill for the abolition of Latin is not appropriate to a period when the nations about us are all desperately striving to reach a higher level of intellectual development in order to participate fully in the progress and increased prosperity of the world. The clause that intends to abolish Latin contains a proposal that will weaken our intellectual and moral weaponry at a time when the circumstances demand that we must strengthen it further.

v. It is to be deeply regretted that some of our Afrikaans secondary schools have allowed Latin to decline as a matriculation subject. It must be acknowledged that the burden on some teachers has thereby been tacitly lightened. Nevertheless, the youth of our nation are entitled to expect of our secondary school system that it realise its responsibility towards country and nation and its intellectual property and that it be prepared to bear its share of the obligation to educate our young people to the required level of intellectual and moral growth.

vi. It is not only highly unwise and utterly dangerous to abolish Latin for attorneys, but also completely unnecessary. All our universities make provision for the teaching of Latin for the benefit of candidates for the attorneys' examinations. Latin will present no problems whatsoever as a subject in the training of attorneys, since every young prospective attorney will have the opportunity to receive training in law at a university, just as our clergymen, doctors, veterinary surgeons, in short, all the practitioners of our learned professions, receive their appropriate training at the universities. It would be wrong to expect young boys in rural towns to work in an attorney's office immediately after matriculating and then to advance on their own without much help and sympathy, and not get the opportunity, like all their classmates, to share for three or four or five years in university life with its educational and formative development of body and mind. Their wish is to spend at least three years at a university. ${ }^{62}$ The thwarting of this wish and the slight emoluments involved are the most important reasons why a rural attorney struggles today to find a willing clerk. This has only a remote connection to Latin. The abolition of Latin will do nothing to improve it.

4. On these grounds the Society of Lecturers in Law urges the Honourable Minister of Education, Arts and Science to delete the clause that aims to abolish Latin. ${ }^{63}$

Prof Smuts added the support of CASA, reminding the new Minister, M D C de Wet Nel, of the Association's views communicated to his late predecessor. ${ }^{64}$

62 This refers to the former practice of indenturing a young person as a pupil with a law firm without his or her being subjected to previous academic legal training (my thanks to one of the referees for this elucidation).

63 Pont to C, 9 September 1958. 


\section{Visit of Prof Wagenvoort}

Details concerning the visit of Prof Wagenvoort were thereafter finalised. The following members of CASA would represent the regional organising committees and host the visitor: Prof Paap (Cape Town), Prof White (Grahamstown), Prof Van Rooy (Bloemfontein), Prof S Davis (Pietermaritzburg), Prof Postma (Potchefstroom), Dr Naudé (Johannesburg), Dr Lubbe (Pretoria) and Prof Smuts (Stellenbosch). ${ }^{65}$

The orthography of Greek proper nouns in Afrikaans

The Secretary-Treasurer wrote to the Suid-Afrikaanse Akademie vir Wetenskap en Kuns (SA Academy of Science and Arts) concerning the proposed project to standardise the spelling of Greek proper nouns in Afrikaans. The Association had elected a small committee to assist the Akademie where possible: Professors Van Rensburg (convener), Gonin, Haarhoff, Van Rooy and Dr E L de Kock. The Akademie welcomed the co-operation. ${ }^{66}$

\section{Co-operation with CARN}

A letter from Dr T F Carney of the Classical Association of Rhodesia and Nyasaland outlined the plans to publish a journal, The Proceedings of the African Classical Association (PACA). The Editorial Board would consist of Prof M Grant (OBE, MA, LittD), Vice-Chancellor, University of Khartoum; Prof W Rollo (DLitt, LittD, University of Cape Town); Prof T B L Webster (MA, FBA), University College, London (British Editor); and Dr T F Carney (BA, PhD), University College of Rhodesia and Nyasaland. Contributions had been offered by Dr E Badian (Durham), Dr H Mattingly Snr (late of the British Museum), Mr B R I Sealey (Bangor), Prof Webster (University College London) and Prof White (Rhodes University). Short summaries of activities of other Classical Associations on the continent would be welcome. Dr Carney also raised the possibility of a cyclostyled newsletter to promote contact between the university colleges and universities in Africa. ${ }^{67}$ Further correspondence followed in which the two associations exchanged information on their activities. ${ }^{68}$

${ }^{64}$ C to Minister Nel, 16 September 1958; receipt acknowledged by Ministry to C, 2 October 1958.

${ }_{65}$ C to Secretary of Education, Arts and Science, 10 May 1957.

66 ST to C, 17 September 1957; Secretary of Fakulteit vir Taal, Lettere en Kuns to ST, 17 December 1957.

67 Carney to Lubbe, undated (1958). The Association was established in 1957; Carney to ST, 11 November 1957; Henderson 2004:97 (where the date 'May 1958' is an error).

68 ST to Carney, 28 May 1958 (with programme of the conference of the Northern Branch held on 26 April 1958); Carney to ST, 3 June 1958; ST to Carney, 7 and 27 June 1958 


\section{The next conference}

Conference matters which occupied the Executive were a letterhead that had been designed showing the Mausoleum at Halicarnassus, which was not to everyone's liking; the dates of the next conference, to be held on 28-31 January 1959 in Bloemfontein; the design and content of the programme; the financial contributions of the universities towards the cost of articles published in Acta Classica by members of their staff; representation at the FIEC conference; the excursion, which was to be to the resort at Mazelspoort; accommodation, again with private individuals; the compilation of a canvassing pamphlet for distribution; and the presentation of the first volume of Acta Classica to Prof Haarhoff at a public ceremony when Prof Steven would deliver the laudatio. ${ }^{69}$ A summary of the history of the Classical Association, including the one founded in 1927, and of the contents of the conference was compiled by Prof Smuts for general circulation. ${ }^{70}$

Prof Smuts's request to the South African Railways for special concessions for delegates was again rejected. ${ }^{71}$ The University of the Witwatersrand decided to pay for first class return rail fares in the case of three members of the Department of Classics. $^{72}$

\section{Conclusion}

The documents recorded here contribute substantially to the account first presented in $2004,{ }^{73}$ not least because they comprise the correspondence of members of the executive. The activities of the formative years of CASA centred around the dayto-day administration, the decisions concerning membership, finances, procedures, conferences and regional branches.

(CASA's formal cognisance of CARN); Carney to ST, 7 July 1958 (acknowledgement with thanks).

69 In reply to ST to E, 1 November 1958: Viljoen to ST, 10 November 1958; Naudé to ST, 18 November 1958; Van Rooy to ST, 17 November 1958; White to C, 29 November 1958; ST to Steven, 14 December 1958; Viljoen to C, 26 December 1958; C to ST, 12 January 1959 (inter alia expressing concern over the 'large amount for the Association' to pay for the excursion, £6.10); C to S Davis, 16 January 1959 (whose offer to deliver a paper was too late as the programme had already been finalised and circulated). The various items were dealt with on the Agendas of the Executive and General Meetings on 27 January 1959. Cf. also Henderson 2004:91-92.

70 Copy on file (undated); also the Chairperson's report for the period 1957-1958; cf. Henderson 2004:100.

71 C to SAR, 9 January 1959; reply 15 January 1959.

72 Registrar (Wits) to ST, 27 January 1959.

73 See Henderson 2004:90-104. 
One of the issues that emerged already then and that was to persist in the years to come, was the position of Latin at schools and universities. Its survival depended (and would depend) on its being required for the study of law. The matter elicited correspondence, statements and reports which were often characterised by narrow, parochial views and attitudes.

A more positive development at this stage was the move to forge international links: the tentative approach by Daphne Hereward, the visit of Professor Wagenvoort (the first by a foreign scholar under the auspices of the Association), the Avignon Conference, membership of FIEC and the relationship with CARN. This international connection was to remain an important, even crucial, feature of the Association.

\section{BIBLIOGRAPHY}

Editors 1958. A report on the Classical Association of South Africa, 1956-1957. AClass 1:164-69.

Editors 1959. Report on the Classical Association of South Africa, 1957-Jan. 1959. AClass 2:126-33.

Henderson, W J 2004. The Classical Association of South Africa: April 1956January 1961. Akroterion 49:89-109.

2013. The Classical Association of South Africa, 1908-1956. Akroterion 58:123-50. 